\title{
Gene Polymorphisms in FAS (Rs3740286 and Rs4064) Are Involved in Endometriosis Development in Brazilian Women, but not those in CASP8 (rs13416436 and rs2037815)
}

\section{Polimorfismos do gene FAS (rs3740286 e rs4064) estão envolvidos no desenvolvimento de endometriose em mulheres brasileiras, mas não os no CASP8 (rs13416436 e rs2037815)}

Cristina Wide Pissetti ${ }^{1}$ Sarah Cristina Sato Vaz Tanaka ${ }^{2}$ Andrezza Cristina Cancian Hortolani ${ }^{2}$ Alessandra Bernadete Trovó de Marqui ${ }^{2}$

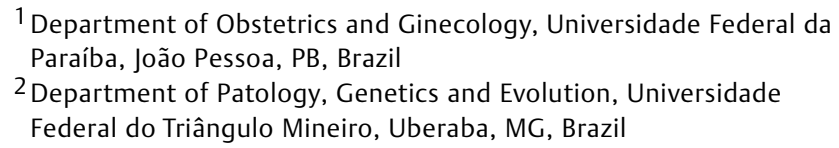

2 Department of Patology, Genetics and Evolution, Universidade Federal do Triângulo Mineiro, Uberaba, MG, Brazil

Address for correspondence Cristina Wide Pissetti, PhD, Departamento de Obstetrícia e Ginecologia, Universidade Federal da Paraíba, Campus I, S/N, Castelo Branco, João Pessoa, PB, 58051-900, Brazil (e-mail: cristinawpissetti@gmail.com).

Rev Bras Ginecol Obstet 2018;40:450-457.

\begin{abstract}
Keywords

- endometriosis

- apoptosis

- genetic polymorphism

- real-time polymerase chain reaction

- genetic predisposition to disease

Objective The present study aims to investigate the association between caspase-8 (CASP8) (rs13416436 and rs2037815) and Fas cell surface death receptor (FAS) (rs3740286 and rs4064) polymorphisms with endometriosis in Brazilian women. Methods In the present case-control study, 45 women with a diagnosis of endometriosis and 78 normal healthy women as a control group were included. The genotyping was determined by real-time polymerase chain reaction (PCR) with Taqman hydrolysis probes (Thermo Fisher Scientific, Darmstadt, Germany). Genotypic and allelic frequencies were analyzed using Chi-squared $\left(\mathrm{x}^{2}\right)$ test. In order to determine the inheritance models and haplotypes ,SNPStats (Institut Català d'Oncologia, Barcelona, Spain) was used. Levels of $5 \%(p=0.05)$ were considered statistically significant.

Results No significant difference was observed in genotypic or allelic frequencies between control and endometriosis groups for rs13416436 and rs2037815 (CASP8 gene). On the other hand, a significant difference between rs3740286 and rs4064 (FAS gene) was found. Regarding polymorphisms in the FAS gene, a statistically significant difference was found in co-dominant and dominant models. Only the haplotype containing the rs3740286A and rs4064G alleles in the FAS gene were statistically significant. Conclusion The polymorphisms in the CASP8 gene were not associated with endometriosis. The results indicate an association between FAS gene polymorphisms and the risk of developing endometriosis.
\end{abstract}

received

May 17, 2018

accepted

May 28, 2018

published online

July 23, 2018
Copyright $\odot 2018$ by Thieme Revinter

Publicações Ltda, Rio de Janeiro, Brazil
License terms

(c) (1) 10.1055/s-0038-1667183. ISSN 0100-7203. 


\section{Resumo}

\section{Palavras-chave}

- endometriose

- apoptose

- polimorfismo genético

- reação em cadeia da polimerase em tempo real

- predisposição genética para doença
Objetivo Investigar a associação entre os polimorfismos dos genes caspase-8 (CASP8) (rs13416436 e rs2037815) e FAS (rs3740286 e rs4064) em mulheres brasileiras com endometriose.

Métodos Trata-se de um estudo do tipo caso-controle, no qual foram incluídas 45 mulheres com diagnóstico de endometriose e 78 controles. A genotipagem das amostras foi determinada usando a reação em cadeia de polimerase em tempo real com sondas de hidrólise TaqMan (Thermo Fisher Scientific, Darmstadt, Germany). As frequências genotípicas e alélicas foram analisadas usando o teste do qui-quadrado. O SNPStats (Institut Català d'Oncologia, Barcelona, Espanha) foi usado para determinar os modelos de herança e os haplótipos. Os níveis de significância estatística considerados foram de $5 \%(p=0,05)$.

Resultados Não foi observada diferença significativa nas frequências genotípicas ou alélicas entre os grupos de controle e de endometriose para os polimorfismos rs 13416436 e rs2037815 (gene CASP8). Por outro lado, foi encontrada uma diferença significativa entre os polimorfismos rs3740286 e rs4064 (gene FAS). Em relação aos polimorfismos do gene $F A S$, foi encontrada uma diferença estatisticamente significativa nos modelos codominante e dominante. Apenas o haplótipo contendo os alelos rs3740286A e rs4064G no gene FAS foi estatisticamente significativo.

Conclusão Não há associação entre os polimorfismos do gene CASP8 e endometriose. Entretanto, há associação entre os polimorfismos do gene FAS e o risco de desenvolver endometriose.

\section{Introduction}

Endometriosis is a multifactorial disease that is characterized by the presence and growth of endometrial glands and stroma outside the uterus. It affects $10 \%$ of women in the reproductive age, and its main clinical manifestations include infertility, chronic pelvic pain, dysmenorrhea, and dyspareunia. ${ }^{1,2}$

Previous studies showed that endometriosis-related symptoms significantly predict a negative impact on the daily life activities, work performance and social and marital life of the patients. ${ }^{3,4}$ In addition, the results of a recent systematic literature review indicated that there is a significant economic burden associated with endometriosis, as observed by both direct and indirect costs. The direct costs included inpatient, outpatient, surgery, drug and other healthcare service costs. The indirect costs were related to absenteeism and presenteeism (loss of productivity at work). ${ }^{5}$

Laparoscopic exploration with histopathological examination is the gold standard for the diagnosis of endometriosis. $^{6}$ During the surgery, lesion excision enables the histological confirmation of endometriosis based on the criteria of the American Society for Reproductive Medicine, ${ }^{7}$ in four stages: I (minimal disease), II (mild disease), III (moderate disease) and IV (severe disease). ${ }^{7}$ To prevent unnecessary surgery, ${ }^{6}$ the identification of a high-risk patient population for endometriosis with a complete clinical assessment should be performed, supported by a selective use of laboratory and imaging studies followed by surgery only on the high-risk population.
In women with endometriosis, the percentage of endometrial cells undergoing apoptosis is significantly decreased. On the other hand, the number of surviving cells is increased, and they still show physiological activity. The eutopic endometrium in women with endometriosis presents an increased expression of anti-apoptotic factor and a decreased expression of pro-apoptotic factors compared with the endometrium in healthy women. These differences could contribute to the survival of regurgitating endometrial cells into the peritoneal cavity and to the development of endometriosis. ${ }^{8,9}$ The data in the literature indicate that apoptosis plays a critical role in the pathogenesis of endometriosis. ${ }^{8-10}$ Another study reviewed the role of apoptosis-associated molecules in the treatment of endometriosis with potential clinical applications in the future. ${ }^{11}$

Single nucleotide polymorphisms (SNPs) in apoptotic genes, such as those of the Fas cell surface death receptor (FAS) and the caspase-8 (CASP8) genes, may be involved with the development of endometriosis.

Caspase-8 is a critical modulator of cell death, which initiates the apoptotic signaling via the extrinsic pathway, and plays a key role in the regulation of apoptosis. ${ }^{12}$

The FAS, also known as TNFSF6, CD95, or APO-1, is a cell surface receptor involved in the apoptotic signal transmission in many cell types that interacts with its natural Fas ligand known as FASL to initiate the death signal cascade that leads to apoptotic cell death. ${ }^{13}$ Although best characterized in terms of its apoptotic function, previous studies have identified several other cellular responses that include migration, invasion, inflammation, and proliferation. ${ }^{14} \mathrm{~A}$ recent study determined that stage III/IV endometriosis was associated with higher 
serum CD95/FAS and hypoxia inducible factor 1 subunit alpha (HIF-1 $\alpha$ ) levels, but not with TEKreceptor tyrosine kinase(Tie-2) levels, compared with stage I/II endometriosis. These biomarkers may be useful for reproductive surgeons to improve the quality of counseling to women about the presence and the severity of endometriosis. ${ }^{15}$

Currently, genome-wide association studies (GWASs) have been very successful in identifying common genetic risk variants for several complex diseases. Genome-wide association studies have reported a significant association of endometriosis with chromosomes 2 and 10, which harbor CASP8 and FAS genes respectively. ${ }^{16-21}$

Therefore, the present study aims to investigate the association between CASP8 (rs13416436 and rs2037815) and FAS (rs3740286 and rs4064) polymorphisms with endometriosis in Brazilian women.

\section{Methods}

\section{Sample Characterization}

This is a case-control study with 123 women treated in a public hospital in the interior of the state of Minas Gerais, Brazil. The women were divided into a control group ( $n=78 ; 63.4 \%)$ and a case group $(n=45 ; 36.6 \%)$. The case group was characterized by the presence of endometriosis, and the control group, by the absence of it, both verified by laparoscopy or laparotomy. The inclusion factors were the surgical procedure that enabled the confirmation of the presence (patients) or absence (controls) of endometriosis, and a written informed consent form (WICF) for the participation in the present research. Women that have not met the aforementioned criteria were excluded. Among the women of the control group, the main reasons for surgical indication were tubal sterilization (24.4\%), followed by chronic pelvic pain (7.7\%) and infertility (6.4\%). The total mean age was $39.1( \pm 9.6)$ years. In the control group, the mean age was 40.7 $( \pm 10.3)$ years, and in the endometriosis group, the mean age was $36.2( \pm 7.8)$ years.

Regarding the endometriosis staging, according to the American Society for Reproductive Medicine (ASRM), ${ }^{7} 6$ women (13.4\%) presented stage I disease, 1 (2.2\%) presented stage II, 7 (15.5\%) presented stage III, 1 (2.2\%) presented stages III/IV, 12 (26.7\%) presented stage IV, and in 18 women (40.0\%) it was not possible to obtain this information.

All participants of the present study received an explanation about the present study and signed the WICF. The present research was approved by the Ethics Committee of Universidade Federal do Triângulo Mineiro (UFTM, in the Portuguese acronym) under protocol number 1628, and was conducted according to the principles described in the Declaration of Helsinki and in Resolution 466/2012 of the Brazilian National Health Council (CNS, in the Portuguese acronym). After signing the WICF, $10 \mathrm{~mL}$ of peripheral blood was drawn by venipuncture from the women who accepted participating in the present research.

\section{DNA Extraction and Genotyping}

Using the salting-out protocol described by Miller et al, ${ }^{22}$ DNA was extracted from the peripheral blood samples collected in an ethylenediaminetetraacetic acid (EDTA) tube. The samples were then resuspended in Tris-EDTA (TE) 20:1, and the DNA integrity was verified in $1 \%$ agarose gel.

The four polymorphisms were genotyped via real-time polymerase chain reaction (PCR) with Taqman hydrolysis probes (Thermo Fisher Scientific, Darmstadt, Germany). The genotypes were determined by allelic discrimination. The chromosomal localizations of the polymorphisms rs13416436 and rs2037815 in the CASP8 gene are Chr.2: 202099113 and Chr.2: 202101715 respectively. The chromosomal localizations of the polymorphism rs3740286 and rs4064 in the FAS gene are Chr.10: 90751340 and Chr.10: 90751380 respectively.

\section{Statistical Analysis}

Hardy-Weinberg equilibrium (HWE) was evaluated by the Chi-squared $\left(\mathrm{X}^{2}\right)$ test, using Haploview 4.2 software (Broad Institute, Cambridge, MA, US), and the case group was in HWE. The statistical power was calculated using the $G^{*}$ Power 3.1.9.2 software (Heinrich-Heine University, Düsseldorf, Germany). A statistical power of $80 \%$ was obtained, with an effect size of 0.29 and an $\alpha$ level of significance of 0.05 . Genotypic and allelic frequencies were analyzed using the Chi-squared test. Levels of $5 \%(p=0.05)$ were considered statistically significant.

SNPStats (Institut Català d'Oncologia, Barcelona, Spain) was used to determine the haplotype and to perform the logistic regressed analysis for inheritance models, using codominant (major homozygotes versus heterozygotes versus minor homozygotes), dominant (major homozygotes versus heterozygotes plus minor homozygotes), and recessive (major homozygotes plus heterozygotes versus minor homozygotes). The risk estimates were expressed as the odds ratio (OR) with a 95\% confidence interval $(95 \% \mathrm{CI})$.

\section{Results}

Concerning the polymorphisms studied, it was not possible to obtain the genotype of all of the participants of the present study, due to technical reasons - no amplification of the sample. For polymorphism FAS rs3740286 (A G) and FAS rs4064 (C G), 116 and 75 of the 123 samples were amplified respectively. For polymorphisms CASP8 rs13416436 (A T) and CASP8 rs2037815 (A G), the number of the samples amplified were 119 and 101 respectively.

For polymorphism FAS rs3740286 (A G), the association between the genotypes of the polymorphism and the development of endometriosis was observed $\left(X^{2}=8.52 ; p=0.014\right)$ (-Table 1). To verify the association, the AG and GG genotypes were grouped in "G presence", and the genotype AA, in " $G$ absence." It was observed that $G$ presence was more frequent in the control group $\left(\mathrm{X}^{2}=8.51 ; p=0.004\right)$. When the OR was calculated, the value obtained was $0.31(95 \% \mathrm{CI}=0.14-0.69)$, suggesting that women with this allele have no presumed risk of developing endometriosis (-Table 2 ).

Regarding the polymorphism FAS rs4064 (C G), there was an association between the genotypes of the polymorphism studied and the development of endometriosis $\left(x^{2}=6.48\right.$; $p=0.039$ ) (-Table 1). To verify the association, the GC and 
Table 1 Frequency distribution of the genotypes of polymorphisms FAS rs3740286 (A G), FAS rs4064 (C G), CASP8 rs13416436 (A T) and CASP8 rs2037815 (A G), in women with endometriosis and in the control group

\begin{tabular}{|c|c|c|c|c|c|c|c|}
\hline \multicolumn{8}{|l|}{ Diagnosis } \\
\hline \multirow[b]{2}{*}{ Polymorphism/genotype } & \multicolumn{2}{|c|}{ Control group } & \multicolumn{2}{|c|}{ Endometriosis } & \multicolumn{2}{|c|}{ Total } & \\
\hline & $n$ & $\%$ & $n$ & $\%$ & $n$ & $\%$ & \\
\hline \multicolumn{8}{|l|}{ rs3740286(A G) } \\
\hline AA & 26 & 51.0 & 25 & 49.0 & 51 & 100 & $p=0.014$ \\
\hline AG & 36 & 76.6 & 11 & 23.4 & 47 & 100 & \\
\hline GG & 14 & 77.8 & 04 & 22.2 & 18 & 100 & \\
\hline Total & 76 & 65.5 & 40 & 34.5 & 116 & 100 & \\
\hline \multicolumn{8}{|l|}{ rs4064 (C G) } \\
\hline CC & 26 & 76.5 & 08 & 23.5 & 34 & 100 & $p=0.039$ \\
\hline GC & 17 & 56.7 & 13 & 43.3 & 30 & 100 & \\
\hline GG & 04 & 36.4 & 07 & 63.6 & 11 & 100 & \\
\hline Total & 47 & 62.7 & 28 & 37.3 & 75 & 100 & \\
\hline \multicolumn{8}{|l|}{ rs13416436 (A > T) } \\
\hline AA & 02 & 100 & 00 & 0.00 & 02 & 100 & $p=0.42$ \\
\hline AT & 15 & 71.4 & 06 & 28.6 & 21 & 100 & \\
\hline TT & 60 & 62.5 & 36 & 37.5 & 96 & 100 & \\
\hline Total & 77 & 64.7 & 42 & 35.3 & 119 & 100 & \\
\hline \multicolumn{8}{|l|}{ rs2037815 (A > G) } \\
\hline $\mathrm{AA}$ & 21 & 60.0 & 14 & 40.0 & 35 & 100 & $p=0.39$ \\
\hline AG & 33 & 64.7 & 18 & 35.3 & 51 & 100 & \\
\hline GG & 12 & 80.0 & 03 & 20.0 & 15 & 100 & \\
\hline Total & 66 & 65.3 & 35 & 34.7 & 101 & 100 & \\
\hline
\end{tabular}

Table 2 Frequency distribution of the presence of the G allele of the polymorphism FAS rs3740286 and FAS rs4064, presence of an allele of the polymorphism CASP8 rs13416436 and presence of the G allele of the polymorphism CASP8 rs2037815, in women with endometriosis and in the control group

\begin{tabular}{|c|c|c|c|c|c|c|c|}
\hline \multicolumn{8}{|l|}{ Diagnosis } \\
\hline \multirow[b]{2}{*}{ G presence rs3740286 } & \multicolumn{2}{|c|}{ Control group } & \multicolumn{2}{|c|}{ Endometriosis } & \multicolumn{2}{|c|}{ Total } & \\
\hline & $n$ & $\%$ & $n$ & $\%$ & $n$ & $\%$ & \\
\hline No & 26 & 51.0 & 25 & 49.0 & 51 & 100 & $p=0.004$ \\
\hline Yes & 50 & 76.9 & 15 & 23.1 & 65 & 100 & $\mathrm{OR}=0.31$ \\
\hline Total & 76 & 65.5 & 40 & 34.5 & 116 & 100 & \\
\hline \multicolumn{8}{|l|}{ G presence rs 4064} \\
\hline No & 26 & 76.5 & 08 & 23.5 & 34 & 100 & $p=0.024$ \\
\hline Yes & 21 & 51.2 & 20 & 48.8 & 41 & 100 & $\mathrm{OR}=3.09$ \\
\hline Total & 47 & 62.7 & 28 & 37.3 & 75 & 100 & \\
\hline \multicolumn{8}{|l|}{ A presence rs13416436 } \\
\hline No & 60 & 62.5 & 36 & 37.5 & 96 & 100 & $p=0.30$ \\
\hline Yes & 17 & 73.9 & 06 & 26.1 & 23 & 100 & $\mathrm{OR}=0.59$ \\
\hline Total & 77 & 64.7 & 42 & 35.3 & 119 & 100 & \\
\hline \multicolumn{8}{|l|}{ G presence rs2037815 } \\
\hline No & 21 & 60.0 & 14 & 40.0 & 35 & 100 & $p=0.41$ \\
\hline Yes & 45 & 68.2 & 21 & 31.8 & 66 & 100 & $\mathrm{OR}=0.7$ \\
\hline Total & 66 & 65.3 & 35 & 34.7 & 101 & 100 & \\
\hline
\end{tabular}

Abbreviation: OR, odds ratio. 
GG genotypes were grouped in "G presence", and the CC genotype was grouped in " $G$ absence." The absence of the $G$ allele was more frequent in the control group $\left(X^{2}=5.06\right.$; $p=0.024)$. When the OR was calculated, the value obtained was $3.09(95 \% \mathrm{CI}=1.14-8.43)$, suggesting that the absence of the $\mathrm{G}$ allele confers a protection 3 times higher against the development of endometriosis in comparison to women who present this allele (-Table $\mathbf{2}$ ).

However, when the polymorphisms in the CASP8 gene were assessed, no association between the polymorphisms studied (rs13416436 and rs2037815) and the development of endometriosis was found. For the polymorphism CASP8 rs13416436 (A T), no association between the genotypes of the polymorphism studied and the development of endometriosis was found $\left(X^{2}=1.71 ; p=0.42\right)(-$ Table 1$)$. The AA and AT genotypes were grouped in "A presence", and the TT genotype was grouped in "A absence" to assess if there was an association between the presence of the A allele and the susceptibility to the development of endometriosis. However, no statistically significant differences were found $\left(\mathrm{X}^{2}=1.06\right.$; $p=0.30 ; \mathrm{OR}=0.59 ; 95 \% \mathrm{CI}=0.21-1.63$ ) (-Table 2).

Regarding the polymorphism CASP8 rs2037815 (A G), there was no association between the genotypes of the polymorphism studied and the development of endometriosis $\left(X^{2}=1.87 ; p=0.39\right.$ ) (-Table 1). The AG and GG genotypes were grouped in " $G$ presence", and the AA genotype was grouped in "G absence" to evaluate if there was an association between the presence of the $G$ allele and the susceptibility to develop endometriosis. However, no statistically significant difference was found $\left(X^{2}=0.68\right.$; $p=0.41 ; \mathrm{OR}=0.7 ; 95 \% \mathrm{CI}=0.3-1.64)$ (-Table 2).

Regarding the polymorphisms rs13416436 (A > T) and rs2037815 (A G) in the CASP8 gene, no statistically significant difference was found in any of the genetic models analyzed (codominant: $p=0.34$ and $p=0.34$; dominant: $p=0.26$ and $p=0.25$; recessive: $p=0.24$ and $p=0.23$ respectively). Regarding the polymorphisms rs3740286 (A $>\mathrm{G})$ and $\mathrm{rs} 4064(\mathrm{G}>\mathrm{C})$ in the FAS gene, a statistically significant difference was found in the codominant and dominant models $(p=0.02, p=0.04 ;$ and $p=0.006$, $p=0.01$ respectively) ( - Table 3 ).

The prevalence of haplotypes in the polymorphisms rs13416436 (A > T) and rs2037815 (A G) in the CASP8 gene, and the rs3740286 $(A>G)$ and $\operatorname{rs} 4064(G>C)$ in the FAS gene is shown in -Table 4. Only the haplotype containing the rs3740286A and rs4064G alleles in the FAS gene was statistically significant $(\mathrm{OR}=0.33 ; 95 \% \mathrm{CI}=0.15-0.72 ; p=0.0062)$.

\section{Discussion}

According to the data in the literature, apoptosis plays an important role in the development of endometriosis. ${ }^{8-10} \mathrm{~A}$ recent review aimed to shed light on the role of the apoptosis pathways in the modulation of the fine-regulated peritoneal microenvironment during endometriosis. ${ }^{23}$ Considering the large amount of evidence retrieved from in vitro as well as in vivo models, the reduced apoptosis of endometriotic cells together with the increased apoptosis of
Table 3 FAS and CASP8 gene polymorphism analysis in different genetic models

\begin{tabular}{|c|c|c|c|}
\hline Gene/SNP & Model & OR $(95 \% \mathrm{Cl})$ & $p$-value \\
\hline \multirow[t]{7}{*}{$\begin{array}{l}\text { FAS } \\
\text { rs3740286 }\end{array}$} & $\begin{array}{l}\text { Codominant } \\
(\mathrm{AA} \times \mathrm{AG} \times \mathrm{GG})\end{array}$ & 1.00 & \\
\hline & & $3.03(1.24-7.41)$ & 0.02 \\
\hline & & $3.24(0.92-11.35)$ & \\
\hline & $\begin{array}{l}\text { Dominant } \\
(A A \times A G+G G)\end{array}$ & 1.00 & \\
\hline & & 3.09 (1.36-6.99) & 0.006 \\
\hline & $\begin{array}{l}\text { Recessive } \\
(A A+A G \times \text { GG) }\end{array}$ & 1.00 & \\
\hline & & 1.99 (0.60-6.59) & 0.24 \\
\hline \multirow[t]{7}{*}{ FAS rs4064 } & $\begin{array}{l}\text { Codominant } \\
\text { (GG x CG x CC) }\end{array}$ & 1.00 & \\
\hline & & $0.35(0.11-1.06)$ & 0.04 \\
\hline & & $0.20(0.04-0.88)$ & \\
\hline & $\begin{array}{l}\text { Dominant } \\
(C C \times C G+G G)\end{array}$ & 1.00 & \\
\hline & & $0.30(0.10-0.84)$ & 0.01 \\
\hline & $\begin{array}{l}\text { Recessive } \\
(C C+C G \text { x GG) }\end{array}$ & 1.00 & \\
\hline & & $0.33(0.08-1.29)$ & 0.11 \\
\hline \multirow[t]{7}{*}{$\begin{array}{l}\text { CASP8 } \\
\text { rs13416436 }\end{array}$} & $\begin{array}{l}\text { Codominant } \\
(\mathrm{TT} \times \mathrm{AT} \times \mathrm{AA})\end{array}$ & 1.00 & \\
\hline & & $1.64(0.56-4.76)$ & 0.34 \\
\hline & & - & \\
\hline & $\begin{array}{l}\text { Dominant } \\
(T T \times A T+A A)\end{array}$ & 1.00 & \\
\hline & & $1.80(0.63-5.16)$ & 0.26 \\
\hline & $\begin{array}{l}\text { Recessive } \\
(T T+A T \times A A)\end{array}$ & 1.00 & \\
\hline & & - & 0.24 \\
\hline \multirow[t]{7}{*}{$\begin{array}{l}\text { CASP8 } \\
\text { rs2037815 }\end{array}$} & $\begin{array}{l}\text { Codominant } \\
\text { (AA x AG x GG) }\end{array}$ & 1.00 & \\
\hline & & $1.49(0.59-3.77)$ & 0.34 \\
\hline & & $2.80(0.64-12.20)$ & \\
\hline & $\begin{array}{l}\text { Dominant } \\
(A A \times A G+G G)\end{array}$ & 1.00 & \\
\hline & & 1.49 (0.59-3.77) & 0.25 \\
\hline & $\begin{array}{l}\text { Recessive } \\
(\mathrm{AA}+\mathrm{AG} \times \mathrm{GG})\end{array}$ & 1.00 & \\
\hline & & $2.21(0.56-8.66)$ & 0.23 \\
\hline
\end{tabular}

Abbreviations: $95 \% \mathrm{Cl}$, 95\% confidence interval; OR, odds ratio.

peritoneal fluid mononuclear cells may address the peritoneal homeostasis to a permissive environment for the progression of the disease. ${ }^{23}$

Endometriosis is a gynecologic condition characterized by the growth of endometrial tissue outside the uterus. Therefore, genes that regulate the growth and the reproduction of endometrial cells and genes that aid the survival of cells and 
Table 4 Haplotype analysis between rs13416436 (A > T) and rs2037815 (A > G) of the CASP8 gene and rs3740286 (A > G) and rs4064 $(G>C)$ in the FAS gene on the risk of developing endometriosis

\begin{tabular}{|l|l|l|l|l|l|}
\hline Gene & Haplotype & ED & Control & OR (95\%Cl) & p-value \\
\hline CASP8 & T-A & 0.6494 & 0.4459 & 1.00 & - \\
\hline & T-G & 0.2824 & 0.4308 & $\begin{array}{l}1.74 \\
(0.89-3.39)\end{array}$ & 0.11 \\
\hline & A-A & 0 & 0.1234 & $\begin{array}{l}2.10 \\
(0.77-5.77)\end{array}$ & 0.15 \\
\hline & A-G & 0.0682 & 0 & & \\
\hline FAS & G-C & 0.2111 & 0.4048 & 1.00 & - \\
\hline & A-G & 0.4489 & 0.2558 & $\begin{array}{l}0.33 \\
(0.15-0.72)\end{array}$ & 0.0062 \\
\hline & A-C & 0.3139 & 0.3231 & $\begin{array}{l}0.66 \\
(0.31-1.39)\end{array}$ & 0.27 \\
\hline & G-G & 0.0262 & 0.0162 & $\begin{array}{l}1.17 \\
(0.07-20.52)\end{array}$ & 0.92 \\
\hline
\end{tabular}

Abbreviations: 95\% Cl, 95\% confidence interval; ED, endometriosis; OR, odds ratio.

eliminate apoptosis are activated..$^{8,9,11}$ This is the reason why, in connection with endometriosis, we have focused on the analysis of polymorphisms associated with apoptosis. It is important to search for biomarkers that could be useful to determine the predisposition and/or the prognosis.

In the present study, we have hypothesized that genetic factors are involved in the etiology of endometriosis; therefore, our aim was to evaluate the genetic predisposition to the development of endometriosis regarding the presence of four polymorphisms: rs13416436, rs2037815, rs3740286 and rs4064.

The polymorphisms rs13416436 and rs2037815 are characterized by an $\mathrm{A} / \mathrm{T}$ and $\mathrm{A} / \mathrm{G}$ single-nucleotide variation respectively, on human chromosome 2, while SNPs rs3740286 and rs4064 are located on chromosome 10 and correspond to $A / G$ and $C / G$ alterations respectively. The present study was the first to analyze the possible associations of these polymorphisms with endometriosis in a Brazilian sample population.

The present study indicated the absence of association between polymorphisms in the CASP8 gene and the risk of developing endometriosis. Our results are in line with a previous study conducted by our group. ${ }^{24}$ There are no studies on the polymorphisms rs13416436 and rs2037815 of the CASP8 gene regarding endometriosis. Only two studies analyzed these polymorphisms in preeclampsia and multiple sclerosis (MS). ${ }^{24,25}$ Orlando et $\mathrm{al}^{24}$ showed the absence of association between rs13416436 and rs2037815 with the development of preeclampsia. However, for SNP rs2037815, GG homozygosity was associated with cases of primary progressive MS when compared with cases of relapse-onset MS and controls. ${ }^{25}$

Previous studies using genome-wide association (GWA) analysis have identified susceptibility genes for endometriosis in chromosome $2 .{ }^{17,18,20,26}$ Adachi et al ${ }^{17}$ showed that four of the top five SNPs were in and around interleukin $1 \alpha$ (IL1A) at 2 q13, which might be a functional candidate gene for endometriosis. Another GWA meta-analysis in 4,604 cases of endometriosis and 9,393 controls identified 7 SNPs associated with endometriosis, 2 of them in chromosome 2 (rs13394619-2p25.1 and rs4141819-2p14). ${ }^{18}$ Sundqvist et $\mathrm{al}^{20}$ observed a weak association with endometriosis (all stages) for rs1250248 in the 2q35 locus $(p=0.049)$. A recent meta-analysis showed a remarkable consistency in endometriosis GWA results across studies, with little evidence of population-based heterogeneity. ${ }^{26}$ It also recommended functional studies in relevant tissues to understand the effect of the variants on downstream biological pathways. ${ }^{26}$ An interesting finding common to these three researches ${ }^{17,18,20}$ was the identification of the polymorphisms associated with endometriosis in chromosome 2 , in which the CASP8 gene, investigated in the present study, is located. However, despite the evidence of the participation of this chromosome in the etiology of endometriosis, the present study has not associated the polymorphism of the CASP8 gene with the disease.

Regarding the two FAS SNPs, our results suggest a significant effect on the susceptibility to endometriosis. Only one study evaluated the three polymorphisms located within the FAS $(-1377 \mathrm{G}>\mathrm{A}$ and $-670 \mathrm{~A}>\mathrm{G})$ and FASL $(-843 \mathrm{C}>\mathrm{T})$ genes as susceptibility factors for endometriosis. ${ }^{27}$ The results indicated that the variants analyzed are not involved in the pathogenesis of the disease in the sample. The authors suggest that a complete genetic analysis of the genes involved in the intricate regulatory system of the apoptosis may lead to the identification of susceptibility factors for the disease and a better understanding of its etiology. ${ }^{27}$ In spite of showing an absence of association between FAS polymorphisms and endometriosis, Fernández et $\mathrm{al}^{27}$ reported that this does not allow us to completely exclude these genes as potential candidates for the disease. Our results corroborate this finding.

Although we have identified an association of polymorphisms in chromosome 10 with susceptibility to endometriosis, another study showed that polymorphisms in the cytochrome P450 family 17 subfamily A member 1 (CYP17A1) and interferon-induced protein with tetratricopeptide repeats 1 (IFIT1) genes in chromosome 10 did not contribute to the risk of endometriosis in the Australian population. ${ }^{28}$ A systematic literature review conducted in 2008 showed that: 1 ) there is evidence of genetic linkage to chromosomes 7 and $10 ; 2$ ) genetic variants in 76 genes were associated with endometriosis; and 3) GWAs are recommended to locate the genetic variants that contribute to a range of common diseases. ${ }^{29}$

The present study is limited due to the small sample size, which decreased our ability to solidify statistic associations. Despite the small sample size, the post hoc statistical power was $80 \%$. Since the endometriosis patients recruited in our study are all Brazilian, the association between these four polymorphisms and other populations should also be investigated. In summary, further studies with different ethnic populations and with a larger sample could help to confirm 
the true significance of the association between these polymorphisms and the risk of endometriosis. Another limitation of the present study was the absence or lack of scientific works on these polymorphisms in endometriosis and other biological conditions, which has made the data generalization and comparison difficult.

A strong point of the present study is that all women who participated (cases and controls) were surgically evaluated to test for endometriosis. In addition, the present work is the first study to focus on the possible contribution of apoptosisrelated gene polymorphisms to the development of endometriosis.

\section{Conclusion}

The polymorphisms in the CASP8 gene are not associated with endometriosis. The results indicate a positive association between the rs 3740286 and rs4064 of the FAS gene and the risk of developing endometriosis. Therefore, further studies on the functional relevance of the CASP8 and FAS polymorphisms are required to confirm our observations.

\section{Contributions}

Cristina Wide Pissetti: conceptualization; formal analysis; funding acquisition; writing of the original draft; writing of the review and editing. Sarah Cristina Sato Vaz Tanaka: formal analysis; methodology; writing of the original draft. Andrezza Cristina Cancian Hortolani: methodology; writing of the original draft. Alessandra Bernadete Trovó de Marqui: conceptualization; formal analysis; writing of the original draft; writing of the review and editing.

\section{Conflicts of Interest}

The authors have no conflicts of interest to declare.

\section{Acknowledgments}

This work was supported by the Conselho Nacional de Desenvolvimento Científico e Tecnológico (CNPq, in the Portuguese acronym) (446914/2014-2).

\section{References}

1 Bulun SE. Endometriosis. N Engl J Med 2009;360(03):268-279. Doi: 10.1056/NEJMra0804690

2 Giudice LC. Clinical practice. Endometriosis. N Engl J Med 2010; 362(25):2389-2398. Doi: 10.1056/NEJMcp1000274

3 Fourquet J, Gao X, Zavala D, et al. Patients' report on how endometriosis affects health, work, and daily life. Fertil Steril 2010;93(07):2424-2428. Doi: 10.1016/j.fertnstert.2009.09.017

4 Pluchino N, Wenger JM, Petignat P, et al. Sexual function in endometriosis patients and their partners: effect of the disease and consequences of treatment. Hum Reprod Update 2016;22 (06):762-774. Doi: 10.1093/humupd/dmw031

5 Soliman AM, Yang H, Du EX, Kelley C, Winkel C. The direct and indirect costs associated with endometriosis: a systematic literature review. Hum Reprod 2016;31(04):712-722. Doi: 10.1093/ humrep/dev335

6 Berker B, Seval M. Problems with the diagnosis of endometriosis. Womens Health (Lond) 2015;11(05):597-601. Doi: 10.2217/ whe.15.44
7 Revised American Society for Reproductive Medicine classification of endometriosis: 1996. Fertil Steril 1997;67(05):817-821. Doi: 10.1016/S0015-0282(97)81391-X

8 Agic A, Djalali S, Diedrich K, Hornung D. Apoptosis in endometriosis. Gynecol Obstet Invest 2009;68(04):217-223. Doi: $10.1159 / 000235871$

9 Taniguchi F, Kaponis A, Izawa M, et al. Apoptosis and endometriosis. Front Biosci (Elite Ed) 2011;3:648-662. Doi: 10.2741/277

10 Harada T, Taniguchi F, Izawa $\mathrm{M}$, et al. Apoptosis and endometriosis. Front Biosci 2007;12:3140-3151. Doi: 10.2741/2302

11 Nasu K, Nishida M, Kawano Y, et al. Aberrant expression of apoptosis-related molecules in endometriosis: a possible mechanism underlying the pathogenesis of endometriosis. Reprod Sci 2011;18(03):206-218. Doi: 10.1177/1933719110392059

12 Tummers B, Green DR. Caspase-8: regulating life and death. Immunol Rev 2017;277(01):76-89. Doi: 10.1111/imr.12541

$13 \mathrm{Xu} \mathrm{Y,} \mathrm{He} \mathrm{B,} \mathrm{Li} \mathrm{R,} \mathrm{et} \mathrm{al.} \mathrm{Association} \mathrm{of} \mathrm{the} \mathrm{polymorphisms} \mathrm{in} \mathrm{the} \mathrm{Fas/}$ FasL promoter regions with cancer susceptibility: a systematic review and meta-analysis of 52 studies. PLoS One 2014;9(03): e90090. Doi: 10.1371/journal.pone.0090090

14 Brint E, O'Callaghan G, Houston A. Life in the Fas lane: differential outcomes of Fas signaling. Cell Mol Life Sci 2013;70(21): 4085-4099. Doi: 10.1007/s00018-013-1327-z

15 Karakus S, Sancakdar E, Akkar O, Yildiz C, Demirpence O, Cetin A. Elevated serum CD95/FAS and HIF- $1 \alpha$ levels, but not Tie-2 levels, may be biomarkers in patients with severe endometriosis: a preliminary report. J Minim Invasive Gynecol 2016;23(04): 573-577. Doi: 10.1016/j.jmig.2016.01.025

16 Treloar SA, Wicks J, Nyholt DR, et al. Genomewide linkage study in 1,176 affected sister pair families identifies a significant susceptibility locus for endometriosis on chromosome 10q26. Am J Hum Genet 2005;77(03):365-376. Doi: 10.1086/432960

17 Adachi S, Tajima A, Quan J, et al. Meta-analysis of genome-wide association scans for genetic susceptibility to endometriosis in Japanese population. J Hum Genet 2010;55(12):816-821. Doi: 10.1038/jhg.2010.118

18 Nyholt DR, Low SK, Anderson CA, et al. Genome-wide association meta-analysis identifies new endometriosis risk loci. Nat Genet 2012;44(12):1355-1359. Doi: 10.1038/ng.2445

19 Albertsen HM, Chettier R, Farrington P, Ward K. Genome-wide association study link novel loci to endometriosis. PLoS One 2013; 8(03):e58257. Doi: 10.1371/journal.pone.0058257

20 Sundqvist J, Xu H, Vodolazkaia A, et al. Replication of endometriosis-associated single-nucleotide polymorphisms from genome-wide association studies in a Caucasian population. Hum Reprod 2013;28(03):835-839. Doi: 10.1093/humrep/des457

21 Rahmioglu N, Montgomery GW, Zondervan KT. Genetics of endometriosis. Womens Health (Lond) 2015;11(05):577-586. Doi: $10.2217 /$ whe. 15.41

22 Miller SA, Dykes DD, Polesky HF. A simple salting out procedure for extracting DNA from human nucleated cells. Nucleic Acids Res 1988;16(03):1215

23 Vetvicka V, Laganà AS, Salmeri FM, et al. Regulation of apoptotic pathways during endometriosis: from the molecular basis to the future perspectives. Arch Gynecol Obstet 2016;294(05):897-904. Doi: 10.1007/s00404-016-4195-6

24 Orlando IC, Tanaka SCSV, Balarin MAS, da Silva SR, Pissetti CW CASPASE-8 gene polymorphisms (rs13416436 and rs2037815) are not associated with preeclampsia development in Brazilian women. J Matern Fetal Neonatal Med 2018;31(03):289-293. Doi: 10.1080/14767058.2017.1285882

25 Camiña-Tato M, Fernández M, Morcillo-Suárez C, et al. Genetic association of CASP8 polymorphisms with primary progressive multiple sclerosis. J Neuroimmunol 2010;222(1-2):70-75. Doi: 10.1016/j.jneuroim.2010.03.003

26 Rahmioglu N, Nyholt DR, Morris AP, Missmer SA, Montgomery GW, Zondervan KT. Genetic variants underlying risk of endometriosis: insights from meta-analysis of eight genome-wide 
association and replication datasets. Hum Reprod Update 2014; 20(05):702-716. Doi: 10.1093/humupd/dmu015

27 Fernández RM, Noval JA, García-Lozano JC, Borrego S, Moliní JL, Antiñolo G. Polymorphisms in the promoter regions of FAS and FASL genes as candidate genetic factors conferring susceptibility to endometriosis. Int J Mol Med 2005;15(05):865-869. Doi: 10.3892/ijmm.15.5.865
28 Zhao ZZ, Nyholt DR, Le L, Treloar SA, Montgomery GW. Common variation in the CYP17A1 and IFIT1 genes on chromosome 10 does not contribute to the risk of endometriosis. Open Reprod Sci J 2008;1:35-40. Doi: 10.2174/1874255600801010035

29 Montgomery GW, Nyholt DR, Zhao ZZ, et al. The search for genes contributing to endometriosis risk. Hum Reprod Update 2008;14 (05):447-457. Doi: 10.1093/humupd/dmn016 